\title{
Powdery Mildew and Nutritional Qualities of Cashew Apple and Kernels
}

\author{
Uaciquete, Americo ${ }^{1}$; Manjate, Cicilia ${ }^{2}$; Muidingui, Lucas ${ }^{2}$. \\ ${ }^{1}$ Instituto de Investigação Agraria de Moçambique, \\ IIAM-Posto Agronómico de Nampula, Centro Zonal Nordeste \\ Rua de Corrane, Km7, C.P. 623; Telf. +258 824062230; Fax. 25826240268 \\ Nampula, Mozambique. *Corresponding author: Email: amuaciquete@gmail.com \\ ${ }^{2}$ Universidade Lúrio \\ Faculdade de Ciências de Saúde \\ Departamento de Nutrição \\ Campus de Marrere, Bairo de Marrere, Rua No. 4250 \\ Km 2,3-Nampula, Mozambique \\ Telf. +25826218250
}

Received: August 6, 2017 Accepted: August 21, 2017 Published: September 21, 2017

doi:10.5296/jas.v5i3.11894

URL: https://doi.org/10.5296/jas.v5i3.11894

\begin{abstract}
In this study we quantitatively evaluated the impact of cashew's powdery mildew on nutritional quality of both apples and nut products. Specifically we assessed $\mathrm{pH}$, Brix, Vitamin $\mathrm{C}$ and the concentration of alcohol on juice, fermented juice and distilled spirit. In addition, kernels from diseased nuts were assessed for moisture, ash, lipids, proteins and carbohydrates content. A completely randomized design with at least three replications was followed in each trial and analysis of variance (ANOVA) performed to check the disease severity categories effect, on nutritional qualities of apples drinkables and kernels. Treatment means were separated by Tukey's test $(P<0.01)$. Apple disease severity significantly increased $\mathrm{pH}$ values of apple juice from 5.22 to 5.34 and 5.47 respectively from healthy, infected and severely infected fruits. Similarly, the amount of Vitamin C increased
\end{abstract}


statistically from 158.92 to 169.02 and $182.15 \mathrm{mg} / \mathrm{ml}$. Finally, Juice Total Soluble Solids (TSS) significantly increased from 13.9 to and 15.1 and $18.9^{\circ}$ Brix. In the wine from healthy, infected and severely infected fruits, $\mathrm{pH}$ values varied from 4.66 to 4.79 and 5.47 respectively. Similar trends were observed in fermented wine and distilled spirit. However, the effect of powdery mildew nut scarification on kernels content in moisture, ash, lipids, proteins and carbohydrates was not statistically significant $(P>0.01)$. In conclusion, powdery mildew disease improved the nutritional qualities of cashew apples derived drinks but caused no effect on nutritional components of the kernels. Therefore in disease endemic regions apple selection is highly recommended for fresh consumption or preparation of cashew drinkables.

Keywords: Oidium anacardii, cashew apples, kernels, nutritional characteristics, Juice

\section{Introduction}

Cashew (Anacardium occidentale L.) is a tropical nut tree native to South America, Brazil being the center of origin (Adeigbe et al., 2015). European conquerors, disseminated the tree between Capricorn and Cancer tropics, during the $16^{\text {th }}$ century (Dandena and Corsi, 2015; Uaciquete and Nicurrupo, 2016). The importance of the crop is mainly associated with its fruit, i.e., the apple and the nut, either as food or medicine or applied in industrial purposes (Yapo and Koffi, 2014; Dandena and Corsi, 2015). The world production of cashew was estimated at 3.7 million tons (FAO, 2014) and therefore about 16 million tons of apples. Mozambique alone, for the 2016 crop season, contributed about 137000 tons of raw nuts. However, cashew production can be significantly hindered, by among other factors, powdery mildew (Oidium anacardii Noack) (Uaciquete and Nicurrupo, 2016). The disease causes considerable damage to young tissues leading to the death of the floral-flushing shoots and the early abortion of young nuts and subsequent loss of yield, mainly in East Africa (Azam-Ali and Judge 2001; Viana et al., 2011). Damage levels, on field, vary depending on the cultivar and/or agro-climatic conditions, but a maximum of $100 \%$ loss in flowers has been observed in East Africa. The disease post harvest impact of the disease includes severe reduction in nut size (Serrano et al., 2013) and subsequent reduction on white wholes kernel recovery during processing (Uaciquete and Nicurrupo, 2016). Meanwhile, when young apples are severely attacked also exhibit reduction in size and longitudinal cracks that exposes the inner part of the fruit to rotting fungi and bacteria (Cardoso et al., 2013; Zhongrun et al., 2013). The main objective of this study was to determine the powdery mildew effect on some nutritional components of cashew apples and nuts derivatives. Specifically, we investigated the apple's disease severity effect on $\mathrm{pH}$, Brix, Vitamin $\mathrm{C}$ and ethanol concentration in drinkables and assessed the nut's disease severity effect on the kernel's content in lipids, proteins, ash, fiber, carbohydrates and moisture.

\section{Materials and Methods}

Fruits were collected at Nassuruma Cashew Research Experimental Station (14 ${ }^{\circ} \mathrm{S} 58^{\prime} 48^{\prime \prime}$; $39^{\circ}$ E 44' 55'), in Nampula Province, Mozambique, during the 2016 crop season. Most of the nutritional variables measurements were made at Food and Water Analysis Laboratory of the Ministry of Agriculture in Maputo, except for $\mathrm{pH}$, Brix and alcohol concentration which were assessed on site. Cashew nut kernels were obtained from a local cashew processing unit, 


\section{Macrothink Institute ${ }^{\mathrm{TM}}$}

Condor Nuts, Anchilo, Nampula, Mozambique (15 S 6' 44"; $39^{\circ}$ E 24' 54"). The lipids, proteins, ash, fiber, carbohydrates and moisture contents were determined at Water and food Laboratory, Ministry of Agriculture and Food Security, in Maputo.

\subsection{Assessment of Apples Juice, Wine and Distilled Spirit Nutritional Qualities}

\subsubsection{Apples Disease Categories}

Mature apples were randomly collected from cashew cultivar 11.2PA. The apples were categorized into three levels of powdery mildew severity (Figure 1A).

Apples of each disease category were washed in distilled water, surface disinfected by swabbing with $70 \%$ ethanol imbibed cotton. They were left at room temperature for an approximately a minute until when the alcohol had dried out. The apples were then squeezed by using clean and ethanol disinfected hands for juice extraction. The juice from individual fruits category was then released into autoclaved glass containers.
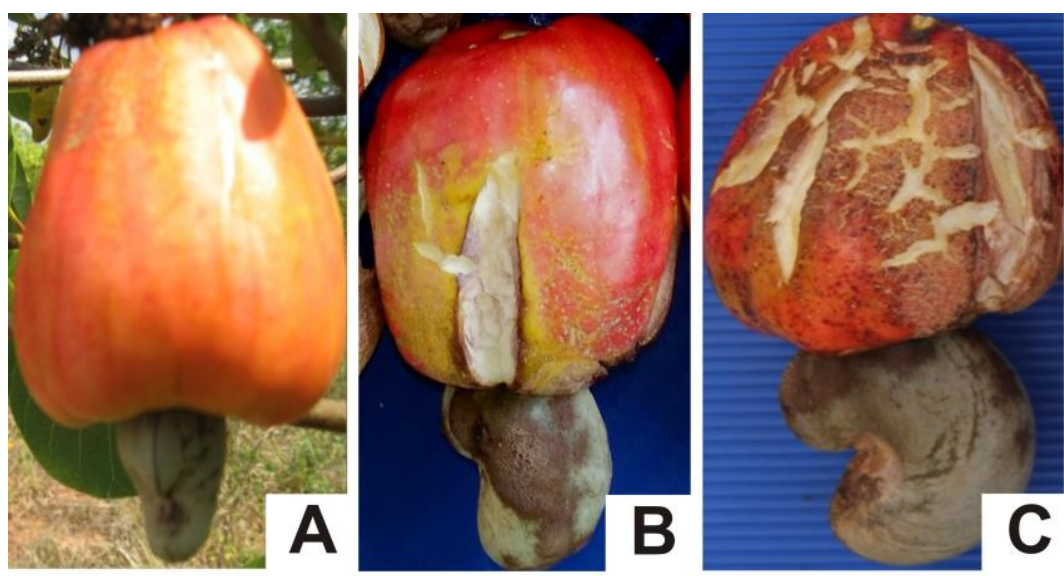

Figure 1. Cashew powdery mildew (Oidium anacardii Noack) severity scale for apples $\mathrm{A}=$ Healthy; $\mathrm{B}=$ Infected and $\mathrm{C}=$ Severely infected fruit.

\subsection{2 $\mathrm{pH}$ Measurements in Juice and Wine}

A digital pH meter (ST Series, Pen Meters, OHAUS Corporation, USA) was used to measure the level of $\mathrm{pH}$ immediately after squeezing the juice. This was achieved by a dipping sensor until when the reading stabilized. Calibration between 4 and 7 was made (Castro et al., 2007). Then, five $\mathrm{pH}$ readings (replicates) were made for each apple scarification level and respective juice. Six replicates were considered for each apple categories for the wine.

\subsubsection{Assessment of Total Soluble Solids (TSS) in juice}

A sterile plastic pipette was used to suck the juice into the pipette and then release a single drop onto a Professional Refractometer (GoerTek Hand-held, 0-30 ${ }^{\mathrm{O}}$ Brix, $20^{\mathrm{O}} \mathrm{C}$ ) for total soluble solids or Brix readings (Harrill, 1998; Castro et al., 2007).

2.1.4 Assessment of Vitamin $\mathrm{C}$ in juice 


\section{MInstitute ${ }^{\text {Mink }}$}

Journal of Agricultural Studies

ISSN 2166-0379

2017, Vol. 5, No. 3

For Vitamin C analysis, juice samples were vortexed into sterile glass bottles, placed in a cool box and then air transported to the Food Laboratory of the Chemistry Department (Engineering Faculty, Eduardo Mondlane University) in Maputo. The samples were then subjected to precipitation of ascorbic acid by potassium iodine procedure (Instituto Adolfo Lutz, 2005) and subsequent calculations made to retrieve Vitamin $C$ content through the following equation Vitamin $C(\%)=\left(100 * V^{*} F\right) / P$; where $\mathrm{V}=$ Volume of iodine used for titration; $\mathrm{F}=8.806$ for $\mathrm{KIO}_{3} 0.02 \mathrm{M}$ and $\mathrm{P}=$ Volume of the sample in milliliters. Four assessments were made for each juice category corresponding to healthy, infected and severely infected apples.

\subsubsection{Determination of Alcohol Content in Distilled Spirit}

From each apple disease severity category, the juice was allowed to ferment in glass jars and then distilled in laboratorial distillation apparatus. The spirit collected was allowed to cool for two days. A conventional alcoholmeter (SNAP 50 Anton Paar, GmbH.) was used to determine the ethanol concentration by dipping the sensor tip into the wine in a sterile glass backer until when the reading was stabilized.

\subsection{Cashew Nuts Disease Categories}

Cashew nuts were selected and grouped into five scarification categories caused by powdery mildew (O. anacardii ) (Figure 2). The nuts were then steam boiled, and the kernels extracted, oven roasted, packed in polyethylene bags and taken to the Water and food Laboratory, Ministry of Agriculture and Food Security, in Maputo.
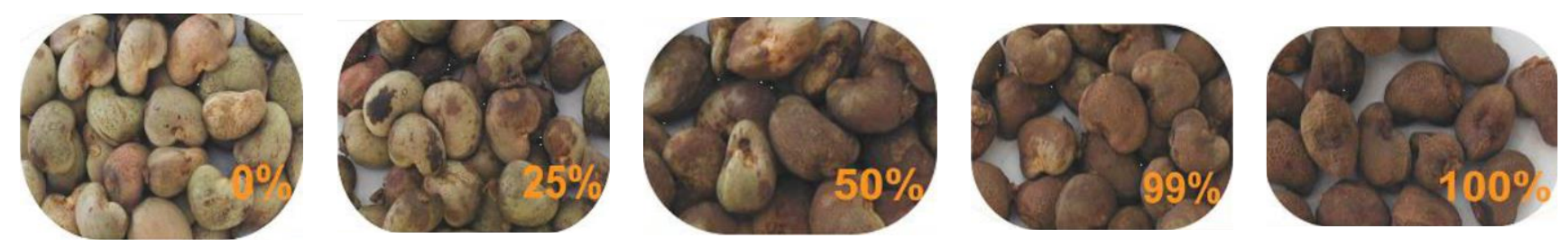

Figure 2. Cashew powdery mildew (Oidium anacardii Noack) severity scale for nuts. From left to right: $0 ; 0-25 ; 25-50 ; 50-99$ and $100 \%$ surface scarified (Uaciquete and Nicurrupo, 2016).

\subsection{Assessment of Cashew Kernels Nutritional Composition}

The following nutritional determinants were evaluated: moisture, proteins, fats, ash, and carbohydrates. Thus, AOAC 2005 No.985.14 official method of analysis was used for moisture determination; AOAC 2005, No. 923.03, No. 984.22 and No.950.48 methods were used for ash, fats and proteins estimation respectively. Similarly, AOAC No. 2001.03 method was followed for determination of fibers content determination and subsequent carbohydrates estimation as described in the following equation from: Carbohydrates $(\%)=100-$ (moisture $\%+$ proteins $\%+$ fats $\%+$ ash $\%$ ), (Brazil, 2003). Three samples (replicates) from each kernel's category were considered for statistical analysis.

\subsection{Statistical Data Processing}




\section{Macrothink}

Journal of Agricultural Studies

ISSN 2166-0379

2017, Vol. 5, No. 3

All the data were analyzed following a completely randomized design and assumptions for ANOVA checked (Petersen, 1994). Thus, data from apple drinkables and kernels were subjected to analysis of variance (ANOVA) by using SAS (Statistical Analysis System, version 9.0, 2002) and means separated through Tukey's test at 0.01 probability level.

\section{Results}

\subsection{Nutritional Components of Cashew Apple Drinks}

\subsubsection{Powdery Mildew Effect on Ph}

Table 1. Analysis of variance (ANOVA) for $\mathrm{pH}$ in cashew juice, wine and spirit produced from powdery mildew (Oidium anacardii Noack) infected apples.

\begin{tabular}{|c|c|c|c|c|c|c|}
\hline Apple drinks & Source & DF & $\begin{array}{c}\text { Type III Sum } \\
\text { of Squares }\end{array}$ & $\begin{array}{l}\text { Mean } \\
\text { Square }\end{array}$ & F Value & $\operatorname{Pr}>F$ \\
\hline Juice & $\begin{array}{c}\text { Powdery } \\
\text { mildew } \\
\text { severity } \\
\text { Error } \\
\text { Total } \\
\end{array}$ & $\begin{array}{c}2 \\
12 \\
14 \\
\end{array}$ & $\begin{array}{l}0.15388000 \\
0.00116000 \\
0.15504000 \\
\end{array}$ & $\begin{array}{l}0.07694000 \\
0.00009667\end{array}$ & 795.93 & $<.0001 * * *$ \\
\hline Fermented wine & $\begin{array}{c}\text { Powdery } \\
\text { mildew } \\
\text { severity } \\
\text { Error } \\
\text { Total } \\
\end{array}$ & $\begin{array}{c}2 \\
12 \\
14 \\
\end{array}$ & $\begin{array}{l}1.8708 \\
0.0047 \\
1.8755 \\
\end{array}$ & $\begin{array}{l}0.9354 \\
0.0004\end{array}$ & 2378.15 & $<.0001 * * *$ \\
\hline $\begin{array}{l}\text { Distilled } \\
\text { Spirit }\end{array}$ & $\begin{array}{c}\text { Powdery } \\
\text { mildew } \\
\text { severity } \\
\text { Error } \\
\text { Total }\end{array}$ & $\begin{array}{c}2 \\
12 \\
14\end{array}$ & $\begin{array}{l}3.6916 \\
0.0126 \\
3.7042\end{array}$ & $\begin{array}{l}1.8458 \\
0.0012\end{array}$ & 1757.89 & $<.0001 * * *$ \\
\hline
\end{tabular}

$C V=$ Coefficient of variation of $(\%)$ for Juice $=0.18$; Fermented wine $=0.39$ and for distilled Spirit $=0.75$.

The apple scarification category associated with powdery mildew showed highly significant effects on $\mathrm{pH}$ levels of juice $(P<0.01)$, fermented wine $(P<0.01)$ and distilled spirit $(P$ $<0.01$ ), as shown in Table 1. 


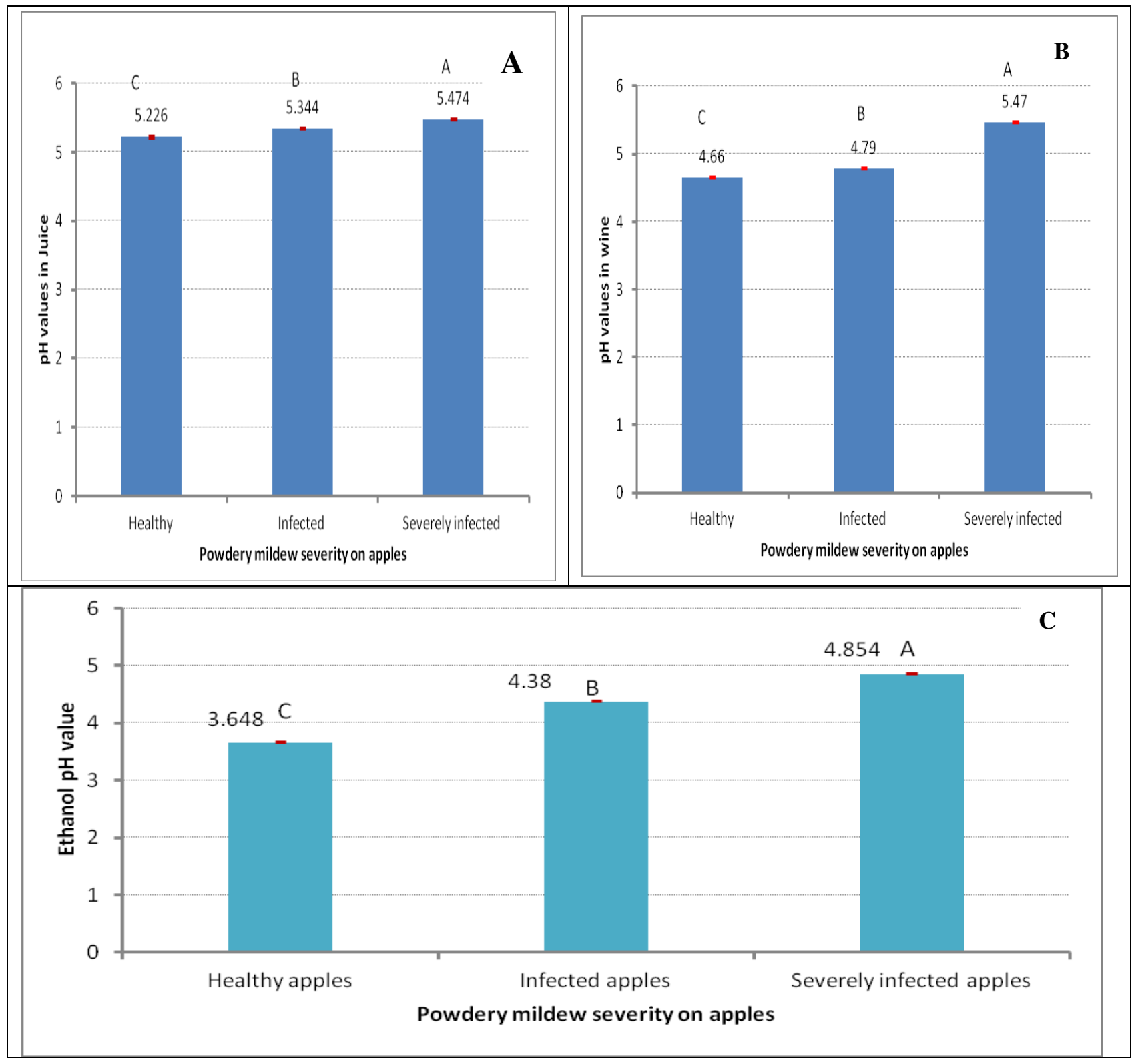

Figure 3. Powdery mildew (Oidium anacardii Noack) effect on $\mathrm{pH}$ values specific to juice, wine and distilled spirit. The little red bars on top represent standard error and capital letters on top of individual bars indicate statistical differences between treatments, by Tukey's test at 0.01 probability level.

The disease severity significantly increases $\mathrm{pH}$ values from 5.226 to 5.344 and 5.474 on healthy, infected and severely infected apples (Figure 3A). Like in juice, pH values significantly increase from 4.66 to 4.79 and 5.47 depending on the disease severity level in fermented wine (Figure 3B) and finally in distilled spirit, highly significant $\mathrm{pH}$ increase from, 3.65 to 4.38 and 4.85 was observed when the severity increases from healthy to severe and severely infected apples respectively (Figure 3C).

3.1.2 Effect Of Powdery Mildew on Total Soluble Solids (TSS) 


\section{Macrothink}

Journal of Agricultural Studies

ISSN 2166-0379

2017, Vol. 5, No. 3

Table 2. Analysis of variance (ANOVA) for TSS in cashew Juice and wine produced from powdery mildew (Oidium anacardii Noack) infected cashew apples.

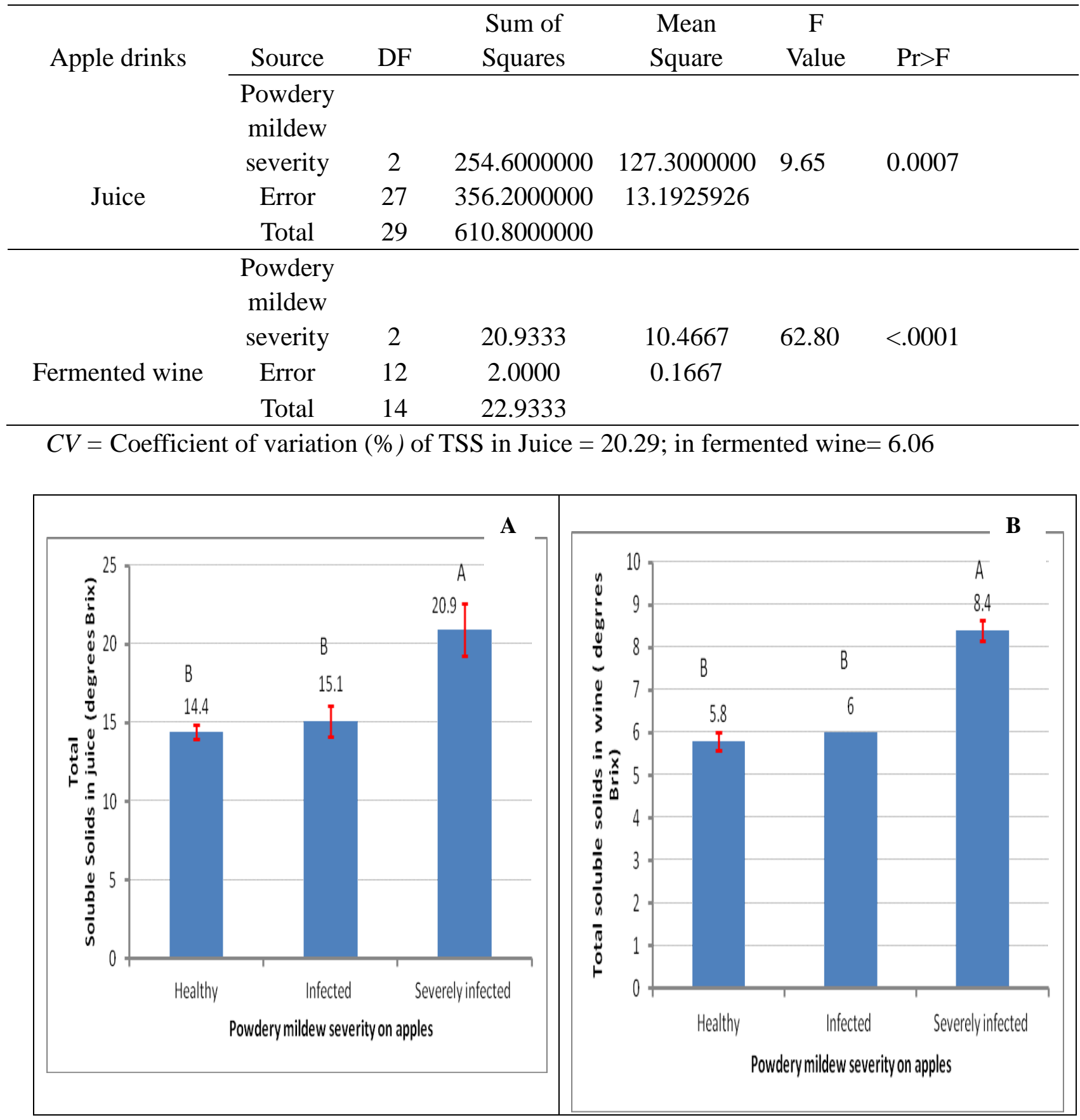

Figure 3. Powdery mildew (Oidium anacardii Noack) effect on TSS of the juice and fermented wine. The little bars on top represent the standard error and capital letters on top of individual bars indicate means statistical differences by Tukey's test at 0.01 probability level. Based on ANOVA (Table 2), highly significant differences $(P<0.01)$ between TSS means associated with the disease severity categories were detected in juice. Similarly, TSS in wine was statistically different $(P<0.01)$ between treatments. Thus, means separations by Tukey's test revealed that an increase in powdery mildew severity results in subsequent increase of TSS in the respective juice, from 14.4 to 15.1 and $20.9^{\circ}$ Brix in cashew cultivar 11.2PA used 


\section{Macrothink}

Journal of Agricultural Studies

ISSN 2166-0379

2017, Vol. 5, No. 3

in this experiment (Figure 3A). In the respective wine, the TSS amount varied from 5.8 to 6 and 8.4 Brix reflecting healthy to infected and severely infected apples respectively (Figure 3B).

\subsubsection{Powdery Mildew Effect on Vitamin C}

Table 3. Analysis of variance (ANOVA) for Vitamin C in cashew Juice produced from powdery mildew (Oidium anacardii Noack) infected cashew apples.

\begin{tabular}{|c|c|c|c|c|c|}
\hline Source & $\mathrm{DF}$ & $\begin{array}{l}\text { Sum of } \\
\text { Squares }\end{array}$ & $\begin{array}{c}\text { Mean } \\
\text { Square }\end{array}$ & $\begin{array}{c}\mathrm{F} \\
\text { Value }\end{array}$ & $\operatorname{Pr}>F$ \\
\hline $\begin{array}{l}\text { Powdery } \\
\text { mildew }\end{array}$ & & & & & \\
\hline severity & 2 & 1085.1868 & 542.5934 & 8.49 & $<0.0085^{* * *}$ \\
\hline Error & 9 & 575.0069 & 63.8897 & & \\
\hline Total & 11 & 1660.1939 & & & \\
\hline
\end{tabular}

$C V=$ Coefficient of variation $(\%)$ for Vitamin $\mathrm{C}=4.70$

As shown in Table 3, highly significant differences were detected on Vitamin $\mathrm{C}$ content of juice extracted from apples with different powdery infection categories. Thus, an increase in content of Vitamin C from 158.92 to 169.024 and $182.15 \mathrm{mg} / \mathrm{ml}$ as powdery mildew severity on apples increased from infected to severely infected, was observed (Figure 4).

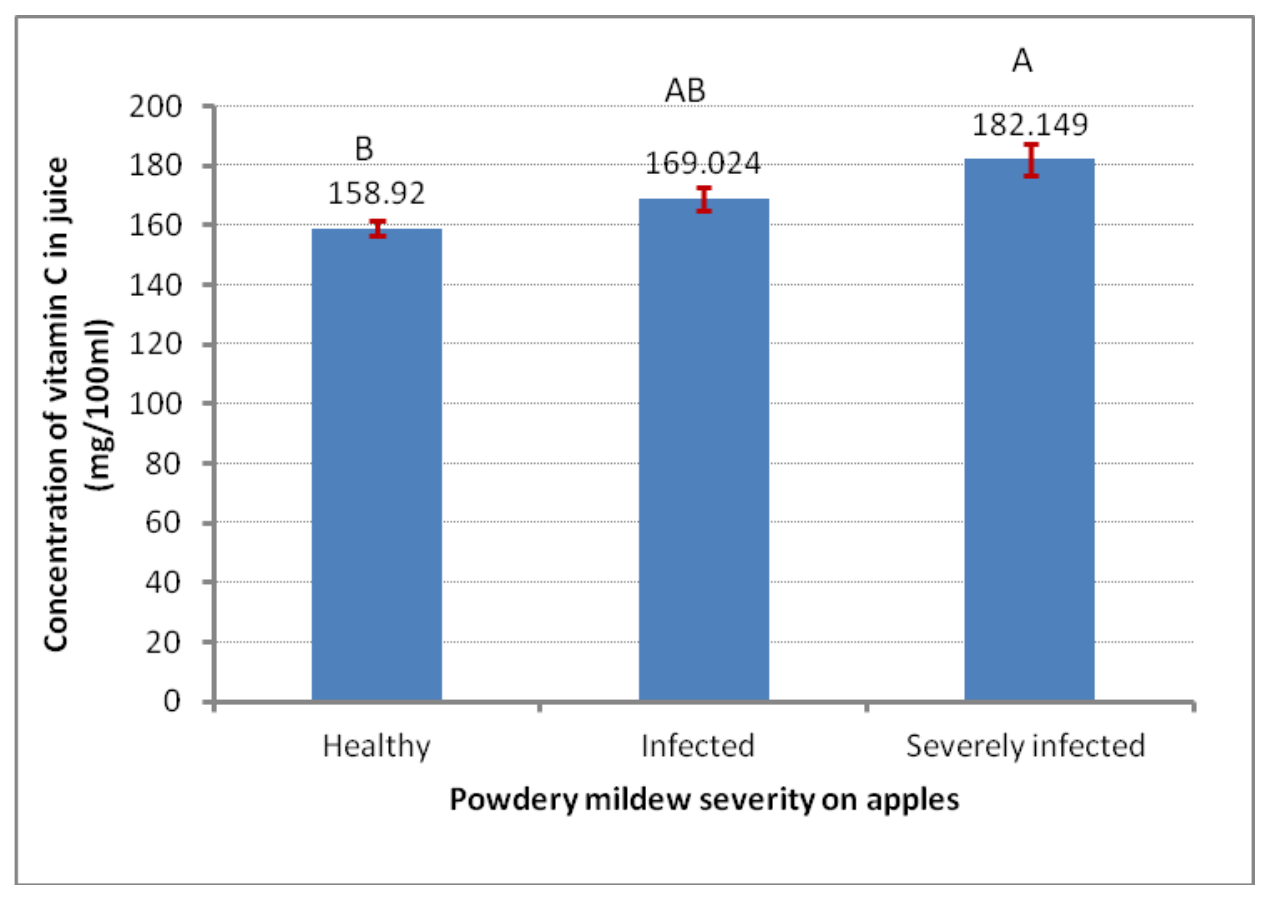

Figure 4. Powdery mildew (Oidium anacardii Noack) effect on Vitamin C of the juice. The little red bars on top represent the standard error and capital letters on top of individual bars indicate means statistical differences by Tukey's test at 0.01 probability level.

\subsubsection{Powdery Mildew Effect on Spirit Alcohol Concentration}


Table 4. Analysis of variance (ANOVA) for alcohol concentration in cashew spirit produced from powdery mildew (Oidium anacardii Noack) infected cashew apples.

\begin{tabular}{ccccccc}
\hline \multirow{2}{*}{ Apple drink } & Source & DF & $\begin{array}{c}\text { Sum of } \\
\text { Squares }\end{array}$ & $\begin{array}{c}\text { Mean } \\
\text { Square }\end{array}$ & $\begin{array}{c}\text { F } \\
\text { Value }\end{array}$ & Pr $>$ F \\
\cline { 2 - 7 } & & & & & & \\
& Powdery & & & & & \\
Alcoholic & mildew & & & & & \\
Spirit & Everity & 2 & 14.8888 & 7.4444 & 67 & $<.0001$ \\
& Total & 6 & 0.6667 & 0.1111 & & \\
& 8 & 15.5556 & & & \\
\hline
\end{tabular}

$C V=$ Coefficient of variation $(\%)=0.82$

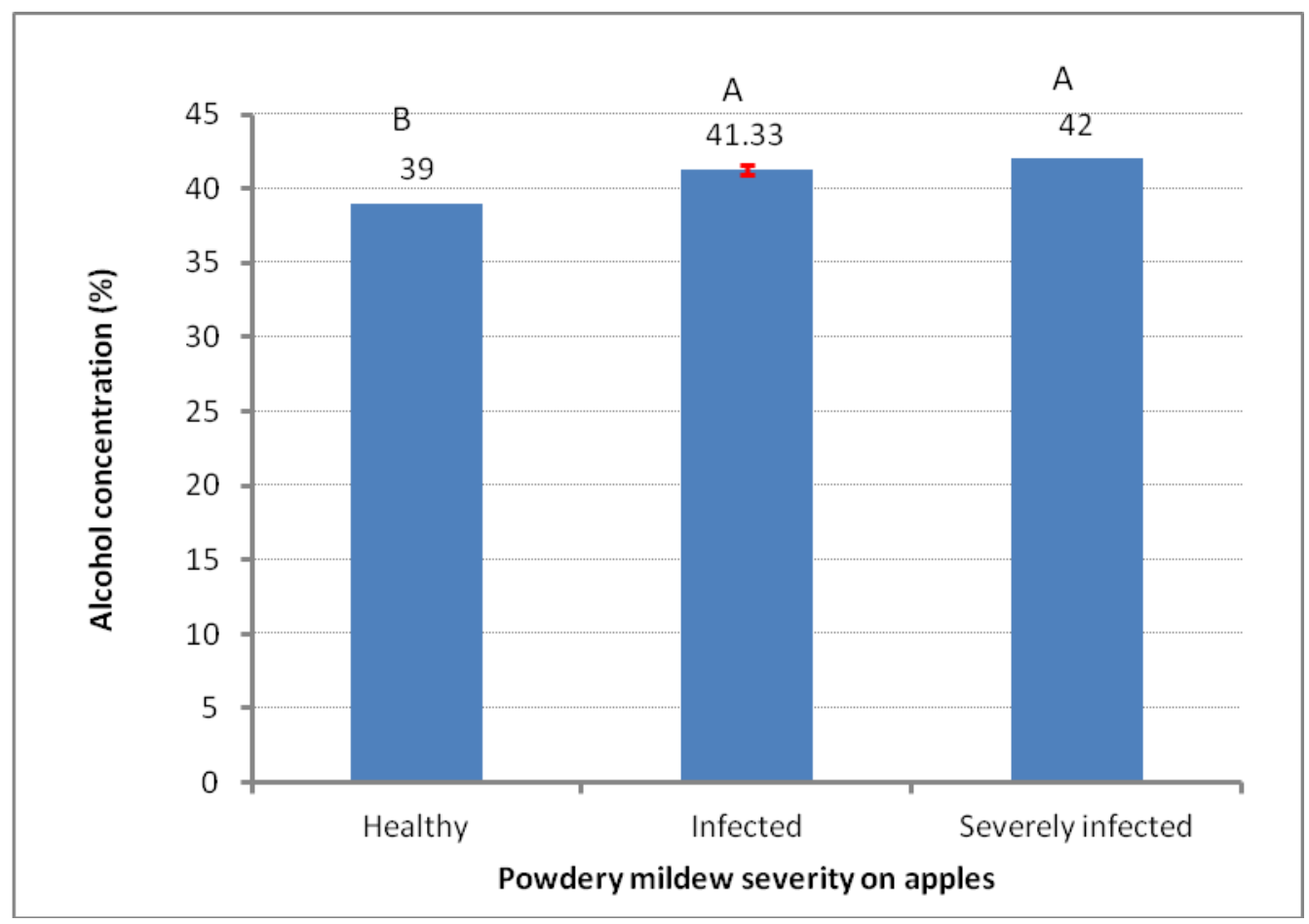

Figure 5. Powdery mildew (Oidium anacardii Noack) effect on Vitamin C of the juice. The little red bars on top represent the standard error and capital letters on top of individual bars indicate means statistical differences by Tukey's test at 0.01 probability level.

Highly statistical differences on alcohol concentration in spirit derived from different categories of diseased cashew apples were detected $(P<0.01)$ (Table 4$)$. The concentration means increased significantly from, 39 in the spirit from healthy fruits to $42 \%$ in that from severely infected apples (Figure 5).

\subsection{Cashew Kernels Nutritional Composition}

Table 5. Analysis of variance (ANOVA) for moisture, fats, ash, proteins and carbohydrates in cashew kernels produced from powdery mildew (Oidium anacardii Noack) infected cashew nuts 


\begin{tabular}{|c|c|c|c|c|c|c|}
\hline Variable & Source & $\begin{array}{l}\text { Degrees } \\
\text { of } \\
\text { Freedom }\end{array}$ & $\begin{array}{l}\text { Sum of } \\
\text { squares }\end{array}$ & $\begin{array}{l}\text { Mean } \\
\text { square }\end{array}$ & F Value & $\operatorname{Pr}>F$ \\
\hline \multirow[t]{3}{*}{ Moisture } & $\begin{array}{l}\text { Powdery } \\
\text { mildew } \\
\text { Severity }\end{array}$ & 4 & 0.0095 & 0.0024 & 0.37 & 0.826 \\
\hline & Error & 10 & 0.0648 & 0.0065 & & \\
\hline & Total & 14 & 0.0744 & & & \\
\hline \multirow[t]{3}{*}{ Ash } & $\begin{array}{l}\text { Powdery } \\
\text { mildew } \\
\text { Severity }\end{array}$ & 4 & 0.2378 & 0.0595 & 1.75 & 0.216 \\
\hline & Error & 10 & 0.3398 & 0.0339 & & \\
\hline & Total & 14 & 0.5776 & & & \\
\hline \multirow[t]{3}{*}{ Fats } & $\begin{array}{l}\text { Powdery } \\
\text { mildew } \\
\text { Severity }\end{array}$ & 4 & 12.6637 & 3.1634 & 1.7 & 0.226 \\
\hline & Error & 10 & 18.6115 & 1.8611 & & \\
\hline & Total & 14 & 31.2651 & & & \\
\hline \multirow[t]{4}{*}{ Proteins } & $\begin{array}{l}\text { Powdery } \\
\text { mildew }\end{array}$ & 4 & 6.7972 & 1.6993 & 3.54 & 0.0478 \\
\hline & Severity & & & & & \\
\hline & Error & 10 & 4.802 & 0.4802 & & \\
\hline & Total & 14 & 11.5992 & & & \\
\hline \multirow[t]{3}{*}{ Carbohydrates } & $\begin{array}{l}\text { Powdery } \\
\text { mildew } \\
\text { Severity }\end{array}$ & 4 & 15.3047 & 3.8262 & 1.27 & 0.3447 \\
\hline & Error & 10 & 30.1632 & 3.0163 & & \\
\hline & Total & 14 & 45.4679 & & & \\
\hline
\end{tabular}

$C V=$ Coefficient of variation $(\%)$ for moisture $=1.54$; for ash $=7.01$; for fats $=3.31$; for proteins $=3.33$ and for Carbohydrates $=5.77$.

Nut powdery mildew disease severity caused no significant differences between kernels in content of moisture $(P>0.01)$, ash $(P>0.01)$, fats $(P>0.01)$, proteins $(P>0.01)$ and carbohydrates $(P>0.01)$ as shown through ANOVA in Table 5. Therefore, no means comparison was made for all variables estimates. However, the results indicate moisture means varying between 5.19 and 5.28\%; ash means, between 2.39 and $2.74 \%$; fats means, between 39.48 and $42.08 \%$; proteins, means between 20.23 and $22.11 \%$ and carbohydrates means, between 29 and $31.99 \%$.

\section{Discussion and Conclusion}

\subsection{Powdery Mildew Effect on $\mathrm{pH}$}

In this study, mean values for $\mathrm{pH}$ in juice varied between 5.236 and 5.474, therefore they increase as the powdery disease severity increases. Meanwhile, the $\mathrm{pH}$ value of 4.52 was 
reported from cashew apple juice in the neighboring South Africa and 5.54 in India (Deenanath et al., 2013). Moreover, Pires et al., (2016) referred to $\mathrm{pH}$ value of 3.5 in Brazil when studying cashew juice composition, while Umashankar et al., (2014) found pH values decreasing from 3.76 to 2.64 during fermentation of cashew juice. A previous study conducted in Mozambique (Ferrão, 1995) showed variations on $\mathrm{pH}$ between 3.55 and 5.00 depending on the origin of the fruit and color of the apple. In general, in Brazil, where numerous studies have been conducted on physicochemical properties of cashew apple juice, $\mathrm{pH}$ values varied between 3.80 and 6.00 (Deenanath et al., 2015). The problem of low pH beverages $(\mathrm{pH}<4.0)$ is high potential of causing dental erosion (Reddy et al., 2016).

In this study, powdery mildew disease has shown to increase $\mathrm{pH}$. Similar results were observed in the case of vine powdery mildew (McFadden-Smith and Pickering, 2006; Devi et al., 2015). Based on Reddy et al., (2016) scale, our juice is minimally erosive to the dental apatite. However, high $\mathrm{pH}$ is unfavorable condition for juice makers, particularly under home conditions of Mozambique, because $\mathrm{pH}$ values above 3.4 are conducive to oxidative reactions and microbial development, yeasts and others associated with apple cracking particular (Figure 1), and thus reduce juice shelf life (Neto et al., 2006; Gomes et al., 2012; Deenanath et al., 2013).

In this study, the wine $\mathrm{pH}$ values increased significantly from 4.66 to 5.47 respectively from healthy to powdery mildew severely infected fruits. Ferrão (1995) in cashew wine made in Mozambique reported a $\mathrm{pH}$ value of 3.6. This is very similar to 3.5 reported by Neto et al., (2006) and Pires et al., (2016). Therefore the current study presents slightly higher values of $\mathrm{pH}$ in fermented wine which in turn significantly increases as the powdery mildew severity increases, probably due to the associated microbial complex.

\subsection{Powdery Mildew Effect on Total Soluble Solids (TSS)}

An increase in powdery mildew severity resulted in significant TSS increase of the respective juice from 13.9 to 18.9 Brix. In Mozambique, Ferrão, (1995) found TSS ranging between 9 and 13 Brix when working with cashew apple juice. It is not clear from the publication, weather the source apples were healthy, mixed or diseased. In Brazil, Costa et al., (2003) and Gomes et al, (2012) found Brix values varying between 10.3 and $11.98^{\circ}$. Pires et al., 2016, determined Brix on cashew juice as 12. In India, Talasila et al., (2011) noted variation on Brix from 13.7 to 14.2 when juice was preserved over time. Therefore, in this study, Mozambican cashew juice has shown relatively high TSS content in juice from severely infected fruits (18.9 ${ }^{\mathrm{O}}$ Brix). According to Ough and Bug, 1979, on grapes, powdery mildewed samples had slightly higher Brix when compared to control. Later, on the same crop, McFadden-Smith and Pickering, (2006), reported significant increase from 23 to $26^{\circ}$ Brix in juice from low to severely infected fruits.

According to this study, an increase of powdery mildew severity, from healthy to severely infected apples, resulted in increased TSS amount in wine from 5.8 to 8.4 Brix. However, compared to respective juice, a decrease in Brix is observed from 13.9 to $5.8(2.4 \mathrm{x})$ in healthy fruits and 18.9 to 8.4 Brix $(5.8 \mathrm{x}$ ) in severely infected ones. Neto et al. (2006) studied the kinetics of juice fermentation and observed a decline in substrate (sugars) due to 
conversion into ethanol. Similarly, a decrease from 20.23 to 15.55 Brix (1.3 x) after 15 days of fermentation was reported by Umashankar et al. (2014). For Jospin et al. (2016) experiment, TSS declined from 10 to 6 Brix (1.6x) after 15 days of fermentation. Crisp et al., (2007) compared both $\mathrm{pH}$ and Brix on juice between powdery mildew fungicide treated and untreated grape fruits and found no significant differences. Our study is in line with Ough and Bug (1979) and McFadden-Smith and Pickering (2006) because Brix in fruit juices reflects the maturity of source fruits and thus good palatability and acceptance (Godoury et al., 2001; Talasila et al. 2011). Therefore, cashew powdery mildew increase on apples surface leads to improved quality of juice and respective wine by increasing Brix.

\subsection{Powdery Mildew Effect on Vitamin C Content}

In the current study, Vitamin C concentration varied between 158.92 and $182.15 \mathrm{mg} / 100 \mathrm{ml}$. In other African countries, Ghana, Nigeria and South Africa, the apple juice content in vitamin $\mathrm{C}$ has been reported to range between 112 and $260 \mathrm{mg} / 100 \mathrm{ml}$ (Deenanath et al., 2013). However, lower value, $70 \mathrm{mg} / 100 \mathrm{ml}$ was reported by Awe et al., (2013) but no association is made with powdery mildew occurrence in all studies above. Our findings are much higher than 80.91 to $121 \mathrm{mg} / 100 \mathrm{ml}$ found in Brazilian cashew juice (Costa et al., 2003; Deenanath et al., 2013) but falls in the range between 164.00-164.67 mg/100 ml reported by Talasila et al., (2011) in India. This variation may be due to variations in climatic growing conditions, fruit harvesting stage and conservation conditions in association with ascorbinase enzyme activity (Ferrão, 1995). Cashew apples contain relatively high amounts of Vitamin C (Almeida et al., 2005). Thus, we demonstrated in this study that powdery mildew even improves the cashew apple juice quality by increasing Vitamin $\mathrm{C}$ concentration.

\subsection{Powdery Mildew Effect on Ethanol Concentration}

Regarding to ethanol chemical quality resulting from distillation of fermented cashew wine, our findings show evidence of a significant increase in $\mathrm{pH}$ from, 3.65 to 4.85 when the severity increases. Similarly, powdery mildew increased ethanol concentration in the spirit from 39 to $42 \%$, probably due to sugar accumulation in the apples as demonstrated in section 4.2 of this article.

\subsection{Powdery Mildew Effect on Nutritional Qualities of Cashew Kernels}

In this study, the proteins content in cashew kernels was quantified ranging between 20.23 and 22.11\%. Previously, Gozalla et al., (2006), Carvalho et al., (2008); Souza et al., (2008) and Rico et al., (2016) in Brazil, found between 14.95 and 21\%. Thus, our results are aligned with the results of these researchers. However, Lima et al., (2004) reported relatively higher values between 24.05 and $36.41 \%$ and Ferrão (1995) reported in the range of 20.75 to $21.83 \%$ for Mozambican kernels and $38.12 \%$ for cashew nuts from Guinea Bissau. Lower values of 18.2 and $18.6 \%$ have also been recorded, Ros, (2010) and Aroyeun, (2009) respectively.

Lima et al., (2004) and Gozalla et al., (2006), reported on the content of fats in cashew kernels ranging between 46.64 and $48.35 \%$. Our findings are of slightly lower magnitude, 39.48 to $42.08 \%$. 
According to Lima et al. (2004), cashew kernel moisture varies in the range of 2.0 to $3.2 \%$. This range is lower compared to our finding (5.19-5.28\%) which in its turn is lower than 7.50 and $8.6 \%$ reported by Ferrão (1995) and (Aroyeun, 2009) respectively.

Ash from cashew kernels in this study varied from 2.39 and $2.74 \%$. This finding is very similar to that of Ferrão (1995), which ranged between 2.52 and 2.69 depending on cashew nut lot and the $2.10 \%$ published by Aroyeun (2009).

In the current study, carbohydrates content was found to range between 29.00 and 31.99 . Aroyeun, (2009), found the percentage of carbohydrates in cashew kernels as 22.84. Later, Rico et al., (2016) reported a mean of $20.5 \%$. Both authors had slightly lower values than our results.

Cashew kernels are associated with high content of healthy lipids that reduces cholesterol levels and coronary heart disease risks (Hu et al. 2001), together with essential proteins to meat adult requirements and minerals that contributes into bones formation and strengthening (Dandena and Corsi, 2015). In this study the powdery mildew effect on quantitative content of nutritional components could not be detected. This is in line with previous observations by Rocha et al., (2015) who found that powdery mildew damage on kernel is proportionally lower compared with that of the nuts.

Considering overall variables in this study, they were quantitatively and reasonably in the range of those reported by other researchers. Therefore, we conclude that powdery mildew disease improves the juice, wine and spirit chemical qualities. However no evidence of nut powdery mildew scarification effect was found on the content of kernels nutritional components. Therefore an appropriate selection of apples before consumption or preparation of drinkables is recommended. Nevertheless, sensorial characteristics of juice and wine or even the spirit were not evaluated throughout this study. Further research is therefore recommended.

\section{Acknowledgements}

The authors wish to thank Dr. Leonel Moiana of the National Agriculture Research Institute-Mozambique and Mr. Elidio Zitha (INCAJU-Nampula) for the scientific review on the manuscript and Mr. Michael Green and Samuel Canda for the language corrections. We also thank Mrs. Helena Matusse (Water and food Laboratory-MASA), Mrs. Iris Sabe (M SC student, Food and Chemistry Laboratory-UEM) for their invaluable laboratorial contribution to this work. Mr. Americo Matos from the cashew processing factory -Condor Nuts, Anchilo and his team who assisted with the grading and processing of cashew nuts. Special thanks to our colleagues at Nassuruma Cashew Research Station and UniLurio CEIL Laboratory for provision of their time and equipment for technical data collection.

\section{References}

Adeigbe, O. O., Olasupo, F. O., Adewale, B. D., \& Muyiwa, A. A. (2015). A review on cashew research and production in Nigeria in the last four decades. Scientific Research and Esseys, 10(5), 196-209. https://doi.org/10.5897/SRE2014.5953. 
Aroyeun, S. O. (2009). Utilization of cashew kernel meals in the nutritional enrichment of biscuit. African Journal of Food Science, 3(10), 316-319.

Awe, S., Sani, A., Eniola, K. I. T., \& Kayode, R. M. O. (2013). Toxicological assessment of locally produced cashew wine. International Journal of Reviews in Applied Sciences, 15(1), $1-17$.

Azam-Ali, S. H., \& Judge, E. C. (2001). Small-scale cashew nut processing. FAO.

Cardoso, J. E., Viana, F. M. P., Freire, F. C. O., \& Martins, M. V. V. (2013). Doenças do cajueiro. In: Agronegócio caju: Práticas e inovações. Brasília, DF [ed. by ARAÚJO, J. P. P.] Embrapa 3(2), 217-38.

Costa, M. C. O., Maia, G. A., Figueiredo, R. W. de., Filho, M. S., \& Brazil, I. M. (2003). Storage stability of cashew apple juice preserved by hot fill and aseptic processes. Ciência e Tecnologia de Alimentos, 23(Supl), 106-09.

Deenanath, E. D., Rumbold, K., \& Iyuke, S. (2013). The Production of Bioethanol from Cashew Apple Juice by Batch Fermentation Using Saccharomyces cerevisiae Y2084 and Vin13. International Scholarly Research Notice: Renewable Energy, 1-11. http://dx.doi.org/10.1155/2013/107851.

Dendena, B., \& Corsi, S. (2015). Cashew, from seed to market: A review. Agronomy for sustainable development, 34(4), 753-772. https://doi.org/10.1007/S13593-014-0240-7.

Devi, V. C., Naveen, J., \& Kannan, P. V. (2015). Process optimization of bio -ethanol production through cashew apple juice fermentation. International Journal of ChemTech Research, 8(1), 79-81.

Fao (2014). Fao statistical yearbook. www.fao.org/3/a-i3590e.pdf

Ferrão, J. E. M. (1995). O cajueiro (Anacardium occidentale L.) Instituto de Investigação Científica Tropical, Lisboa, Portugal, 298.

Francisca, N. B. R., Suane de Oliveira S. B., Eveline N. de L., Ingrid B. de L., Lívia, K. R. M., \& José, E. C. (2015). Influência do oídio em castanhas do cajueiro CCP 76. XV Encontro de Pós-graduação e Pesquisa, 19 a 23 de Outubro. Universidade de Fortaleza.

Gadoury, D. M., Seem, R. C., Pearson, R. C., Wilcox, W. F., \& Dunst, R. M. (2001). Effects of powdery mildew on vine growth, yield and quality of Concord grapes. Plant Disease. 85, 137-140. https://doi.org/10.1094/PDIS.2001.85.2.137.

Gazolla, J., Gazolla, R., Coelho, C. H., Wander, A. E., \& J. R. O. (2006). A Amêndoa da Castanha de caju: Composição e Importância dos Ácidos Graxos - Produção e Comércio Mundiais. Grupo de Pesquisa: Ciência, Inovação Tecnológica e Pesquisa. XLIV Congresso da Sober; 23 a 27 de Julho; Fortaleza, Brazil.

Gomes, M. J. N., Kader, Y. N. A. M., Ellensohn, R. M., da Cunha, M. E. T., \& Barin, C. S. (2012). Analise fisico-quimica de suco de caju concentrado. Centro Científico Conhecer, Goiânia. Enciclopédia Biosfera, 8(15), 2019-2024. 


\section{$\triangle$ Macrothink}

Journal of Agricultural Studies

ISSN 2166-0379

2017, Vol. 5, No. 3

Harrill, R. (1998). Using refractometer to test quality of fruits \& vegetables. Pineknoll Plublishing. Rex Hill. Keedysville, 28.

Hu, F. B., Manson, J. E., Willett, W. C. (2001). Types of dietary fat and risk of coronary heart disease: a critical review. J. Am. Coll. Nutr. 20, 5-19.

https://doi.org/10.1080/07315724.2001.10719008

Instituto Adolfo Lutz (2005). Normas analíticas do Instituto Adolfo Lutz: Métodos químicos e físicos para análises de alimentos. $4^{a}$ ed., 1. Brasília, 1018.

Jospin, D. A., Mouaimine, M., Fidele, T. P., N'krumah O, B. C. C. K., \& Mohamed, S. M. (2016). Valorization of cashew apples for bioethanol production by alcoholic fermentation. International Journal of Advanced Research, 4(10), 683-689.

Lima, A. C. dos S., Garcia, N. H. P., \& Lima, J. R. (2004). Obtenção e caracterização dos principais produtos do caju. Boletim do Centro de pesquisa e processamento de alimento, 22, 133-144.

McFadden-Smith, W., \& Pickering, G. (2005). Effect of powdery mildew on fruit quality. Ramdane Dris. (ed.), Crops: Quality, Growth and .Biotechnology, 882-891. WFL Publisher, Meri-Rastilantie 3C, 00980 Helsinki, Finland.

Mohanty, S., Ray, P., Swain, M. R., \& Ray. R. C. (2016). Fermentation of cashew (Anacardium occidentale L.) apple into wine. Journal of Food Processing and Preservation, 30, 314-322. https://doi.org/10.1111/j.1745-4549.2006.00067.x

Narendranath, N. V., \& Power, R. (2005). Relationship between $\mathrm{pH}$ and Medium dissolved solids in terms of growth and metabolism of Lactobacilli and Saccharomyces cerevisiae during ethanol production. Applied and environmental microbiology, 71(5), 2239-2243.

https://doi.org/10.1128/AEM.71.5.2239-2243.2005

Neto, A. B. T., da Silva, M. E., Silva, W. B., Swarnakar, R., \& da Silva, F. L. H. (2006). Cinética e caracterização físico-química do fermentado do pseudofruto do caju (Anacardium occidentale L.). Quimica Nova, 29(3), 489-492.

Ough, C. S., \& Berg, W. H. (1979). Powdery mildew sensory effect on wine. Am. J. Enol. Vitic., 30(4), 321.

Petersen, R. G. (1994). Agricultural field experiments. Design and Analysis. Marcel Deckker, Inc. New Yourk, USA. 409.

Pires, T. P. R., Almeida, L. S., Pereira, E. S., \& Carmo, I. C. L. (2016). Parametros físico-quimicos do fermentado do caju (Anacardium Occidentale L.) produzido na fazenda cajucoco. X CIGR Section IV International Technical Symposium. Food: the tree that sustains life. 24-27 de Outubro .

Reddy, A., Norris, D. F., Momeni,S. S., Waldo, B., \& Ruby, J. D. (2016). The pH of beverages in the United States. Journal of American Dental Association, 147(4), 255-263. https://doi.org/10.2016/j.adaj.2015.10.019.Epub2015Dec2. 


\section{I Macrothink}

Journal of Agricultural Studies

ISSN 2166-0379

2017, Vol. 5, No. 3

Rico, R., Bulló, M., \& Salas-Salvadó, J. (2016). Nutritional composition of raw fresh cashew (Anacardium occidentale L.) kernels from different origin Food Science \& Nutrition, 4(2), 329-338. https://doi.org/10.1002/fsn3.294.

Rocha, F. N. B., Brazil, S. D. S., de Lima, E. N., de Lima, I. B., Maia, L. K. R., \& Cardoso, J. E. (2015). Influência do oídio em castanhas do cajueiro CCP 76. XV encontro de pós-graduação e pesquisa. 19-23 October. Universidade de Fortaleza, Fortaleza, Brazil.

Ros, E. (2010). Health benefits of nut consumption. Nutrients 2(7), 652-682.

https://doi.org/10.3390/nu2070652.

Serrano, L. A. L., Neto, F. C. V., Melo, D. S., \& Cardoso, J. E. (2013). Influência do oidio nas castanhas de diferentes genótipos do cajeuiro. [Influence of the powdery mildew in cashew nuts genotypes]. Embrapa 40. Boletim de Pesquisa e Desenvolvimento, V Serie, 76 (1), 1-22.

Talasila, U., Vechalapu, R. R., \& Shaik, K. B. (2011). Preservation and shelf life extension of cashew apple juice. Internet Journal of Food Safety, 13, 275-280.

Uaciquete, A., \& Nicurrupo, J. R. (2016). Direct effect of cashew nut scarification associated with powdery mildew in the processing industry. Journal of Agricultural Studies, 4(3), 74-92. https://doi.org/10.5296/jas.v4i3.9881.

Umashankar, N., Mohan, C., Benherlal, P. S., \& Maruthesh. A. M. (2014). Standardization of fermentation process for the production of cashew wine. International Journal of Science and Nature., 5(2), 226-230.

Yapo, B. M., \& Koffi, K. L. (2014). Extraction and characterization of highly gelling low methoxy pectin from cashew apple pomace. Foods, 3(1), 1-12.

https://doi.org/10.3390/foods3010001.

Zhongrun, Z., Lihong, L., \& Uaciquete, A. (2013). Diseases and insect pests of cashew in Mozambique. Tropical Crops Genetic Resources Research Institute, CATAS. China Agriculture Press, 99.

\section{Copyright Disclaimer}

Copyright for this article is retained by the author(s), with first publication rights granted to the journal.

This is an open-access article distributed under the terms and conditions of the Creative Commons Attribution license (http://creativecommons.org/licenses/by/4.0/). 